\title{
HPV in exhaled breath condensate of lung cancer patients
}

\section{GE Carpagnano*,', A Koutelou', MI Natalicchio'², D Martinelli', C Ruggieri', A Di Taranto', R Antonetti', F Carpagnano ${ }^{4}$ and MP Foschino-Barbaro'}

'Institute of Respiratory Disease, Department of Medical and Occupational Sciences, Faculty of Medicine, University of Foggia, Foggia, Italy; ${ }^{2}$ III Laboratory of Analysis, Department of Clinical Pathology, Riuniti Hospital Foggia, Foggia, Italy; ${ }^{3}$ Department of Medical Sciences, Section of Hygiene, Faculty of Medicine, University of Foggia, Apulia Regional Epidemiological Observatory, Foggia, Italy; ${ }^{4}$ Department of Thoracic Surgery, Case di Cura Riunite,

La Madonnina, Bari, Italy

BACKGROUND: A recent intriguing carcinogenetic hypothesis for lung cancer foresees its viral aetiology. The human papilloma virus (HPV) is the main virus actually recognised in the pathogenesis of lung cancer. The aim of this study was to investigate, for the first time to our knowledge, the presence of HPV in the exhaled breath condensate (EBC) of lung cancer patients.

MATERIALS AND METHODS: We enrolled 89 patients affected by lung cancer and 68 controls. HPV infections were investigated in their EBC, paired bronchial brushing and neoplastic lung tissue through genotyping.

RESULTS: We were able to detect HPV in the EBC, bronchial brushing and neoplastic lung tissue. We described the presence of an HPV infection in $16.4 \%$ of the subjects affected by non-small cell lung cancer, but in none of the controls. HPV I6 and 31 turned out to be the most widespread genotypes. The HPV positivity in airways as well as in the smoking habit was seen to independently increase the individual's susceptibility to developing lung cancer.

CONCLUSION: When summing up, we demonstrated the possibility to identify an HPV infection in the EBC of lung cancer patients; further, we supported the notion that the EBC is a suitable tool to study airway colonisation. That being said, although further studies are needed to confirm our results, we retain the study of HPV in EBC to be very interesting in terms of future programmes involving lung-cancer screening.

British Journal of Cancer (201 I) 105, I I83- I190. doi:10.1038/bjc.201 I.354 www.bjcancer.com

Published online 27 September 2011

(c) 20II Cancer Research UK

Keywords: human papilloma virus; bronchial brushing; breath condensate; lung cancer

A viral aetiology of lung tumours is a tantalising prospect since the virus can be regarded as a main oncogenic event or as an important co-factor (Brouchet et al, 2005). At another level, the possibility that the human papilloma virus (HPV), a small doublestranded DNA virus that belongs to the family of papillomaviridae, contributes to the pathogenesis of lung cancer is an intriguing hypothesis (Menon et al, 1995; De Villiers et al, 2004). In 1979, Syrjänen was the first to suggest that HPV was involved in lung cancer (Syrjänen, 1979). After an initial description, several other studies subsequently confirmed his findings (Tsuhako et al, 1998; Castillo et al, 2006; Ciotti et al, 2006; Aguayo et al, 2007; Nadji et al, 2007) until the arrival of Harald zur Hausen, who, in 2008, was conferred the Nobel Prize of physiology and Medicine for this discovery (Zur Hausen et al, 1974).

At present, more than $100 \mathrm{HPV}$ serotypes have been identified (Cubie, 2003). The oncogenic HPV types associated with bronchopulmonary carcinoma include types $16,18,31,33$, whereas types 6 and 11 are non-oncogenetic (Clavel et al, 2000). The overall HPV prevalence ranged from 0.0 to $78.3 \%$ with large heterogeneity across geographic regions and histological tissue types (Srinivasan et al, 2009). The incidence of HPV in lung cancer in Europe is $17 \%$ (Klein et al, 2009).

Human papilloma virus infection and metaplasia in lung tissue may increase an individual's susceptibility to

*Correspondence: Dr GE Carpagnano; E-mail: ge.carpagnano@unifg.it Received 13 May 201 I; revised 2 August 2011; accepted 4 August 201 I; published online 27 September 2011 tumourigenesis (Chen et al, 2004). The key oncogenic mechanism of HPV is mediated by its ability to interfere with the cell-cycle and tumour-suppressive function of the cell through its oncoproteins E6 and E7 that inactivate p53 and Rb proteins, respectively (Werness et al, 1990; Kessis et al, 1993; Zur Hausen, 2001, 2002).

The presence of HPV in the airways of lung cancer patients has already been investigated through research of the virus in bronchial aspirates (Papadakis et al, 2002; Branica et al, 2010), fresh lung tissue (Papadopoulou et al, 1998; Clavel et al, 2000; Zafer et al, 2004; Coissard et al, 2005; Ciotti et al, 2006; Wang et al, 2008) and paraffin-embedded lung tissue (Béjui-Thivolet et al, 1990; Shamanin et al, 1994; Szabó et al, 1994; Hirayasu et al, 1996; Bohlmeyer et al, 1998; Tsuhako et al, 1998; Kaya et al, 2001; Syrjänen, 2002; Fei et al, 2006). However, confirming studies on these samples is difficult, as they are invasive and poorly accepted by patients.

An increasing interest in the study of lung cancer is currently being directed to the use of techniques that allow collecting non-invasiveness samples such as exhaled breath condensate (EBC).

Several soluble and genetic markers have already been measured in the EBC of lung cancer patients and investigated as early neoplastic markers, although none of them have been validated sufficiently for clinical application. In regards to the possibility to analyse viral or bacterial colonisation in EBC, studies on pseudomonas, burkholderia and the influenza virus were found to be unsuccessful (Vogelberg et al, 2003; St George et al, 2010). 
The aim of this study was to investigate, for the first time to our knowledge, the presence of HPV in the EBC of lung cancer patients. In order to verify more effectively whether EBC reflects airways infection, we analysed the HPV in EBC, paired bronchial brushing and neoplastic lung tissue of those patients affected by lung cancer and of the controls.

\section{MATERIALS AND METHODS}

\section{Characteristics of the patients}

A total of 157 consecutive patients with a suspicion of lung cancer (44 F, $118 \mathrm{M}, 66.9 \pm 11.6$ years) that consented to the study were enrolled at the Unit of Thoracic Surgery, Casa di Cura La Madonnina, Bari, as well as at the Department of Respiratory Disease, Foggia University (Table 1). Written informed consent was obtained from all subjects upon approval of the study by the Ethics Committees of the two hospitals.

All patients were enrolled in the study before pathological diagnosis. All patients also underwent standard staging procedures consisting in a physical examination, serum chemistry analysis, brain, chest and abdomen CT scans and radionuclide bone scan.

All the patients underwent thoracotomy except for six of them, who were deemed surgically inoperable for reasons related to staging and/or inadequate cardiorespiratory functioning.

In these cases the definitive diagnosis of malignancy derived from a positive cytohistology of the samples obtained broncosco-

Table I Demographic and clinical data of subjects enrolled

\begin{tabular}{|c|c|c|}
\hline & Lung cancer patients & Healthy subjects \\
\hline$N$ & 89 & 68 \\
\hline $\operatorname{Sex}(M / F)$ & $72 / 17$ & $41 / 27$ \\
\hline Age (years) & $68.2 \pm 11.3$ & $66.8 \pm 4.8$ \\
\hline FEVI (\%) & $92.2 \pm 4.1$ & $91.3 \pm 3.4$ \\
\hline FVC (\%) & $97.2 \pm 3.1$ & $96.1 \pm 2.9$ \\
\hline \multicolumn{3}{|l|}{ Histological type } \\
\hline Squamous cell carcinoma & 36 & - \\
\hline Adenocarcinoma & 37 & - \\
\hline Small cell lung cancer & 16 & - \\
\hline Bronchial pneumonia & - & 32 \\
\hline Bronchogenic cyst & - & 2 \\
\hline Hamartomas & - & 6 \\
\hline Mycetomas & - & 7 \\
\hline Pulmonary abscess & - & 7 \\
\hline Pulmonary tuberculoma & - & 6 \\
\hline Endothoracic neurinoma & - & 3 \\
\hline Klemperer's tumour & - & 2 \\
\hline \multirow[t]{2}{*}{ Typical carcinoid } & - & 3 \\
\hline & - & \\
\hline \multicolumn{3}{|l|}{ TNM stage of lung cancer } \\
\hline I & 18 & - \\
\hline$\|$ & 15 & - \\
\hline III & 28 & - \\
\hline IV & 21 & - \\
\hline \multicolumn{3}{|l|}{ Smoking habits } \\
\hline Current smokers & 67 & 51 \\
\hline Ex-smokers & 17 & 8 \\
\hline Non-smokers & 5 & 9 \\
\hline \multicolumn{3}{|l|}{ PAP test } \\
\hline Positive & 0 & 0 \\
\hline Negative & 24 & 17 \\
\hline
\end{tabular}

Abbreviations: $\mathrm{F}$ =female; $\mathrm{FEVI}=$ forced expiratory volume in I second $\mathrm{FVC}=$ forced vital capacity; $\mathrm{M}=$ male; $\mathrm{PAP}=$ papanicolaou; $\mathrm{TNM}=$ tumour nodes metastasis. pically. Following the histological analysis carried out on specimens, 68 subjects turned out to be negative and were considered as controls. All 68 patients were operated on and the definitive diagnosis is shown in Table 1 . In the remaining 89 subjects, the suspicions of lung cancer were confirmed. Squamous cell carcinoma was diagnosed in 36 subjects, whereas 37 subjects were found to be affected by adenocarcinoma and 16 by small-cell lung cancer. Overall the patients were classified as stage I in 18 cases, stage II in 15 cases, stage III in 25 cases and stage IV in 21 cases.

All subjects underwent EBC and bronchial brushing collection (the latter was carried out during bronchoscopy). Their paraffinembedded neoplastic lung tissue, collected during lung surgery, was stored for successive analysis.

We acquired information on their smoking habit at the time of diagnosis. In all, 67 of the lung cancer patients were current smokers ( $43.5 \pm 11.6$ packs per year), whereas 17 were ex smokers $(42.9 \pm 18.6$ packs per year) and 5 were non-smokers. On the other hand, in the controls group fifty-one were current smokers $(40.6 \pm 10.3$ packs per year), eight were ex smokers $(39.9 \pm 16.5$ packs per year) and nine were non-smokers. A detailed history relating to their family history of lung cancer or any other cancer was collected in a pre-tested pro-form. All the women enrolled underwent a PAP smear test and were evaluated as cytological using the Bethesda system for PAP smear interpretation along with colposcopic evaluation. We considered negative samples where koilocytosis was absent.

\section{Bronchial brushing collection and processing}

Bronchial brushing specimens were collected in ice-cold phosphate-buffered saline solution during the fibreoptic bronchoscopy and were stored at $-70{ }^{\circ} \mathrm{C}$ for subsequent analysis.

DNA extraction was performed using qiasymphony (Qiagen, Hilden, Germany), following the manufacturer's instructions.

\section{EBC collection and processing}

The above required $1 \mathrm{ml}$ of $\mathrm{EBC}$ in one setting from each patient at the time of diagnosis.

The EBC was collected by using a condenser, which allowed for the non-invasive collection of the non-gaseous components of the expiratory air (EcoScreen Jaeger, Wurzburg, Germany). The condensate was collected in ice at $-20^{\circ} \mathrm{C}$, transferred to $1.5 \mathrm{ml}$ polypropylene tubes and immediately stored at $-70^{\circ} \mathrm{C}$ for subsequent analysis.

DNA extraction was performed using qiasymphony (Qiagen) following the manufacturer's instructions.

\section{Paraffin-embedded lung tissue processing}

Formalin-fixed and paraffin-embedded neoplastic lung tissue were sectioned at a thickness of $10 \mu \mathrm{m}$ and used for each patient for DNA extraction purposes.

At the beginning, one slide of lung tissue was treated with ematossilin eosin for the selection of the neoplastic lung area. Next, from the area selected neoplastic material was asported and put into two separate $1.5-\mathrm{ml}$ polypropylene tubes. After that samples were deparaffinised in xylene and then rehydrated through serial dilutions of alcohol. After evaporation, the DNA was extracted and purified with a DNA Qiamp mini-kit (Qiagen) that foresaw the first step of enzymatic digestion with an ATL buffer and proteinase $\mathrm{K}$ overnight at $56^{\circ} \mathrm{C}$. For the second step, we added lysis buffer $\mathrm{AL}$ and carried out incubation at $70^{\circ} \mathrm{C}$ for $10 \mathrm{~min}$, whereas the further step involved purification by the addition of absolute ethanol and passage through ion-exchange column chromatography followed by washing and finally the use of elution buffer AE with DNA in a volume proportional to the starting material. 


\section{Measurement of HPV DNA}

The HPV DNA was analysed in DNA from EBC, bronchial brushing and lung tissue.

The assay for HPV genotyping was initially performed using an HPV sign (Diatech, Jesi, Italy).

The DNA was amplified by PCR reactions with one of the primers biotinylated on Rotor-Gene TM 6000 (Corbett Research, Sydney, Australia), whereas single-stranded DNA templates were prepared using the PyroMark Vacuum Prep Workstation (Biotage, Uppsala, Sweden).

The pyrosequencing analysis was performed on the PyroMarkTM Q96 ID instrument (Biotage).

Pyrosequencing is a DNA-sequencing technique to determine nucleic acid sequences. This method is a sequencing-by-synthesis technique that employs a series of enzymatic reactions to accurately detect short nucleic acid sequences during DNA synthesis. In principle, when a complementary nucleotide is incorporated by DNA polymerase into an already-primed DNA template (whereby the sequencing primer is hybridised to target the DNA), an inorganic pyrophosphate (PPi) molecule is released. The released PPi is converted to ATP by ATP sulphurylase using adenosine phosphosulphate as substrate. This reaction provides energy for the conversion of luciferase to oxidase luciferin, and consequently the light produces a peak in the pyrogram (c.f. electropherogram in Sanger sequencing). Each signal peak is proportional to the number of nucleotides incorporated (e.g., a triple dTTP nucleotide incorporation generates a triple higher peak). Apyrase is a nucleotide-degrading enzyme, which continuously degrades the ATP and non-incorporated dNTPs in the reaction mixture. There is a certain time interval between each nucleotide dispensation to allow for complete degradation. For this reason, one nucleotide addition is performed at a time. During the sequencing-by-synthesis process, the primed-DNA strand is extended by complementary nucleotides, and the DNA-sequence signals are displayed by the signal peaks in a pyrogram on a computer monitor. Base callings are performed with integrated software with features for related SQA and sequencing analysis. HPV 16 and HPV 30 pirograms and relative melt curves are reported in Figures 1 and 2.

The INFINITI HPV-QUAD assay was successively used to confirm the HPV results.

The AutoGenomics HPV-QUAD assay targets the $E 1$ gene of the HPV genome. Multiplex PCR for five individual HPV types $(16,18$, 31,33 and 45), five combinations of HPV types $(35 / 68,39 / 56$, $58 / 52,59 / 51$ and $6 / 11$ ) and a $\beta$-globin internal control were performed on extracted DNA using Platinum TaqDNA Polymerase (Invitrogen, Carlsbad, CA, USA) and an amplification mix was provided with the INFINITI HPV-QUAD Assay (AutoGenomics, Carlsbad, CA) as previously reported (Erali et al, 2009).

\section{Statistical analysis}

In order to assess the association between categorical variables such as sex, smoking habit or HPV positivity and positivity to lung cancer, or between histological subtypes or TNM stage and HPV positivity, the $\chi^{2}$-test or (Fisher's exact test, when it was necessary) and odds ratio (OR) with relative confidence intervals (95\% CI) were calculated. The $t$-Student's test for independent samples was used to assess the differences in continuous variables (age, number of packs/years smoked) between lung cancer patients and controls.

An exact logistic regression model was performed in order to state the possible confusing effect among the variables, in the comparison between the NSCLC and the healthy controls. A $P$-value of $<0.05$ was considered statistically significant.

Sensibilities, specificity, positive and negative predictive values with relative confidence intervals of $95 \%$ were calculated for cytology, as well as for cytology in association with the HPV test (in brushing or EBC). Statistical analysis was carried out using STATA 10 MP for the MAC OS X software package (TStat S.r.l., Sulmona, Italy). The data were analysed by the Department of Medical Sciences, Section of Hygiene, University of Foggia.

\section{RESULTS}

The number of lung cancer cases and healthy subjects enrolled in the present study was 89 and 68, respectively. Demographic and clinical data of study subjects are summarised in Table 1 .

The male sex was associated as having NSCLC $(\mathrm{OR}=3.3$, $95 \% \mathrm{CI}=1.84-7.8 ; \chi^{2}=9.46, P=0.0021$ ).

For the first time we were able to detect an HPV infection in the EBC. In only one EBC sample we observed a low concentration of viral DNA (measured spectrophotometrically and resulting as not being dosable) that did not allow for the evaluation of HPV positivity.

Eleven NSCLC patients (15.1\%) turned out to be HPV positive on the EBC. Of these six were positive to HPV-16 and three to HPV-31 (genotype at high risk for cancer), one to HPV-30 and one to HPV-39. Comparing the NSCLC-positive patients with the controls who were not affected by tumours (the SCLC have been excluded from the analysis) it was shown that being HPV positive to the EBC increases the probability of being affected by NSCLC (Fisher's exact $P=0.002$, degree of freedom $=1$ ).

A total of 12 NSCLC patients (16.4\%) turned out to be HPV positive on the bronchial brushing and lung tissue. Of these, seven were positive to HPV-16 and three to HPV-31 (genotype at high risk for cancer), one to HPV-30 and one to HPV-39. Comparing the NSCLC-positive patients with the controls who were not affected by tumours (the SCLC have been excluded from the analysis) it was shown that being HPV positive to the bronchial brushing and lung tissue increases the probability of being affected by NSCLC (Fisher's exact $P=0.0011$, degree of freedom $=1$ ).

Paired samples analysed (EBC, bronchial brushing and lung tissue) showed, except in one case, an overlap of the HPV positivity spectrum.

All controls turned out to be negative to HPV both in the EBC and in the paired brushing and lung tissue.

The HPV results were confirmed in all the samples of those subjects analysed with the INFINITI HPV-QUAD assay.

Comparing the NSCLCs to the healthy controls (SCLCs have been excluded from the analysis) using sex as a criterion, being smokers/ex smokers, being HPV positive on the brushing and HPV positive on the EBC as variables in logistic regression models, either being smokers/ex smokers or HPV positive (in EBC, bronchial brushing or lung tissue) will increase the risk of having an NSCLC (Tables 2, 3 and 4).

Higher percentages of HPV positivity in the EBC, bronchial brushing or lung tissue were observed in adenocarcinoma than in squamous cell carcinoma, although the difference did not reach a statistical significance (Table 5 - Fisher's test, $P>0.05$ ). On the other hand, none of the SCLC patients showed HPV positivity in the EBC, brushing or lung tissue. HPV-positive patients were those with TNM stage $>2$ (Fisher's test, $P<0.05$ ). Neither sex, age nor smoking habit were found to be associated with a more advanced stage of lung cancer or to HPV positivity. The association of cytology with the HPV test (in the EBC, brushing or lung tissue) slightly increases the sensibility of the test (Table 6).

\section{DISCUSSION}

The main result in this study was the presence of HPV positivity in the EBC, in addition to the paired bronchial brushing and neoplastic lung tissue of lung cancer patients compared with the complete HPV negativity in controls. For the first time in this study we were able to detect HPV infection in the EBC. The positivity to HPV both in the $\mathrm{EBC}$ and in the bronchial brushing 
A IdentiFire

Detailed report

Sample ID:

Well: $\quad$ C1

PSQ run: $\quad$ 2009/10/10_HPVD'AVANZO

Entry ID: $\quad$ 2009/10/10_HPV

Sequence library: HPV library_rev3 (2010-03-31, 8:29:58 AM)

Query sequence: AACTACATATAAAAATACTAACTTTAAGGA

$\begin{array}{lll}\text { Result: Human papillomavirus type } 16 & \text { Score: } 100\end{array}$

Quality: $\quad$ Good

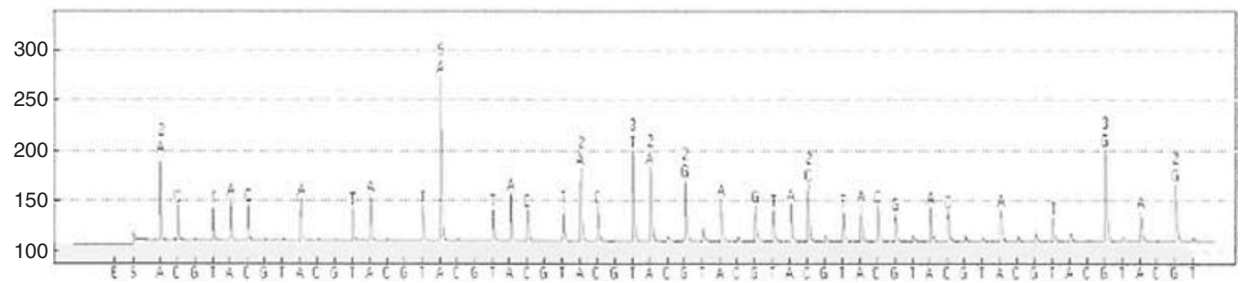

\begin{tabular}{ll} 
Hit 1: & Human papillomavirus type 16 \\
\hline Score: & 100
\end{tabular}

Identities: $\quad 30 / 30(100 \%)$

Gaps: $\quad 0 / 30(0 \%)$

Query 1 AACTACATATAAAATACTAACTTTAAGGA 30

IIIIIIIIIIIIIIIIIIIIIIIIIIIIII

Library 1 AACTACATATAAAAATACTAACTTTAAGGA 30

Hit 2: $\quad$ Human papillomavirus type 16 (African type 1)

Score: $\quad 94.1$

Identities: $\quad$ 29/30 (97\%)

Gaps: $\quad 0 / 30(0 \%)$

Query 1 AACTACATATAAAAATACTAACTTTAAGGA 30

111111111111111111111111111111

Library 1 AactacataTaAaAaTactaactTTtanga 30

\begin{tabular}{|c|c|c|}
\hline Sample ID: & CTRL1/2 & \\
\hline Well: & B1 & \\
\hline PSQ run: & 2009/10/10_HPVD'AVANZO & \\
\hline Entry ID: & 2009/10/10_HPV & \\
\hline Sequence library: & HPV Library_rev3 (2010-03-31, 8:29:58 AM) & \\
\hline Query sequence: & GATACTACATTTAAAAGTAGTAATTTTAAA & \\
\hline Result: & man papillomavirus type 31 & score: 100 \\
\hline Quality: & & \\
\hline
\end{tabular}

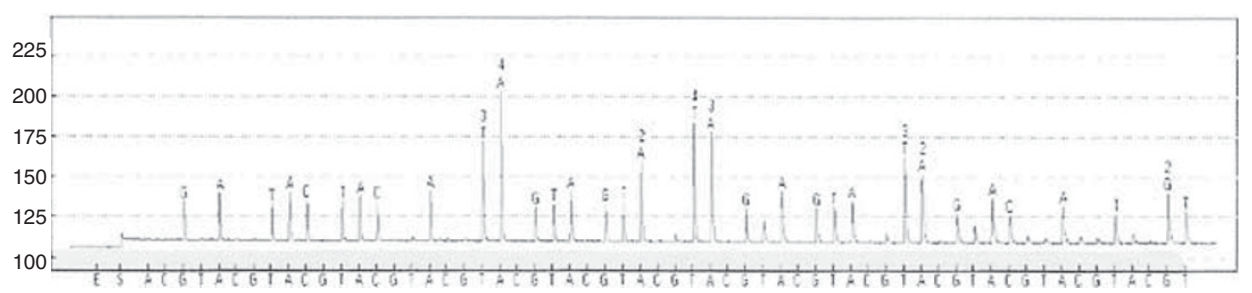

\begin{tabular}{|c|c|c|}
\hline Hit 1: & & Human papillomavirus type 31 \\
\hline Score: & & 100 \\
\hline Identities: & & $30 / 30(100 \%)$ \\
\hline Gaps: & & $0 / 30(0 \%)$ \\
\hline Query & 1 & $\begin{array}{l}\text { GATACTACATTTAAAGGAGTAATTTAAA } \\
111111111111111111111111111111\end{array}$ \\
\hline
\end{tabular}

Figure I HPV 16 (A) and HPV 30 (B) pirograms.

and in the lung tissue as well as the smoking habit were found to be an independent factor in increasing the probability of causing the NSCLC. Furthermore, the association of the positivity of the cytology and the HPV test (in EBC, brushing or lung tissue) slightly increases the sensibility of malignant diagnosis.
The great interest in the viral aetiology of lung cancer recently produced several studies on blood-borne HPV in the other local samples of lung cancer patients (Béjui-Thivolet et al, 1990; Shamanin et al, 1994; Szabó et al, 1994; Hirayasu et al, 1996; Bohlmeyer et al, 1998; Tsuhako et al, 1998; Kaya et al, 2001; 

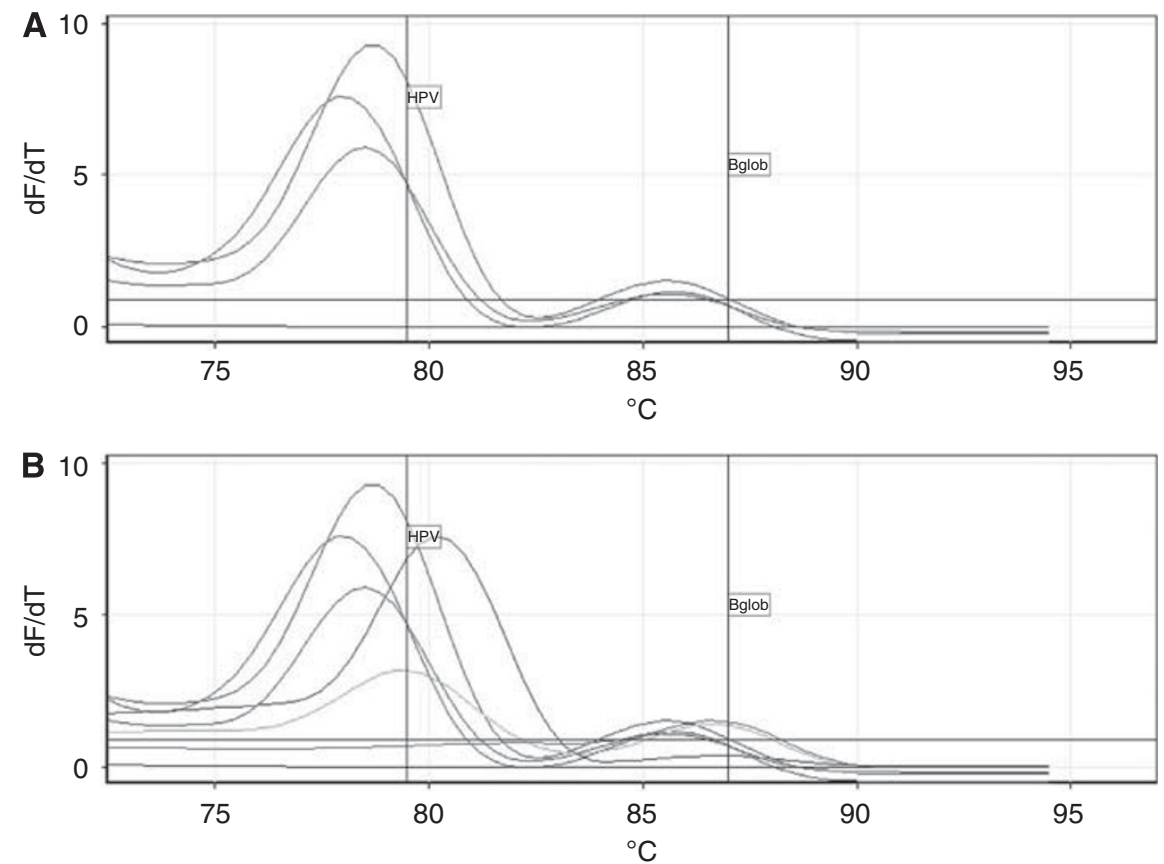

Figure 2 Melt curves $(\mathbf{A}$ and $\mathbf{B})$.

Table 2 Number of NSCLC subjects and controls by sex, smoking habits and HPV+ (in the brushing and lung tissue or in the EBC), ORs (95\% $\mathrm{Cls}$ ) and $P$-values

\begin{tabular}{|c|c|c|c|c|c|}
\hline & Controls & NSCLC & Total & $P$ & OR $(95 \% \mathrm{Cl})$ \\
\hline \multicolumn{6}{|l|}{ Sex } \\
\hline $\mathrm{F}$ & 27 & 12 & 39 & 0.002 & $3.34(1.4-8.1)$ \\
\hline M & 41 & 61 & 102 & & \\
\hline Total & 68 & 73 & $|4|$ & & \\
\hline \multicolumn{6}{|c|}{ Smokers/ex-smokers ${ }^{\mathrm{a}}$} \\
\hline N & 28 & 12 & 40 & 0.001 & $3.6(1.5-8.5)$ \\
\hline Y & 40 & 61 & 101 & & \\
\hline Total & 68 & 73 & $|4|$ & & \\
\hline \multicolumn{6}{|c|}{ HPV+ in the brushing and lung tissue } \\
\hline $\mathrm{N}$ & 68 & 61 & 129 & 0.0005 & - \\
\hline$Y$ & 0 & 12 & 12 & & \\
\hline Total & 68 & 73 & $|4|$ & & \\
\hline \multicolumn{6}{|c|}{$H P V+$ in the $E B C$} \\
\hline $\mathrm{N}$ & 68 & 62 & 130 & 0.0009 & - \\
\hline Y & 0 & 11 & 11 & & \\
\hline Total & 68 & 73 & $|4|$ & & \\
\hline
\end{tabular}

Abbreviations: $\mathrm{Cl}=$ confidence interval; $\mathrm{EBC}=$ exhaled breath condensate; $\mathrm{F}=$ female; $\mathrm{HPV}=$ human papilloma virus; $\mathrm{M}=$ male; $\mathrm{N}=$ no; $\mathrm{NSCLC}=$ non-small cell lung cancer; $\mathrm{OR}=$ odds ratio; $Y=$ yes. ${ }^{\mathrm{a}}$ Average number of cigarette packs per year: $41.8 \pm 18.5$

Syrjänen, 2002; Fei et al, 2006). Although the research of other viruses or bacteria in the EBC was previously reported as unsuccessful (Vogelberg et al, 2003; St George et al, 2010), we set out to investigate this sample for HPV in lung cancer patients or subjects at risk as smokers. The complete non-invasiveness of the EBC makes it a more tempting option as compared with other samples, especially in the field of screening subjects at risk.

In disaccordance with other studies showing that EBC is not a tool for detection of pseudomonas, burkholderia and influenza
Table 3 Number of HPV+/- (in the brushing and lung tissue or in the $\mathrm{EBC})$ subjects by sex and smoking habits, ORs (95\% Cls) and $P$-values

\begin{tabular}{|c|c|c|c|c|c|}
\hline & $\mathbf{N}$ & $\mathbf{Y}$ & Total & $P$ (Fisher) & OR $(95 \% \mathrm{Cl})$ \\
\hline \multicolumn{6}{|c|}{ HPV+ in the brushing and lung tissue } \\
\hline \multicolumn{6}{|c|}{ Sex } \\
\hline $\mathrm{F}$ & 37 & 2 & 39 & $>0.05$ & $2(0.4-19.7)$ \\
\hline M & 92 & 10 & 102 & & \\
\hline Total & 129 & 12 & $|4|$ & & \\
\hline \multicolumn{6}{|c|}{ Smokers/ex-smokers ${ }^{\mathrm{a}}$} \\
\hline $\mathrm{N}$ & 33 & 7 & 40 & 0.04 & $0.3(0.06-0.97)$ \\
\hline Y & 96 & 5 & 101 & & \\
\hline Total & 129 & 12 & $|4|$ & & \\
\hline \multicolumn{6}{|c|}{$H P V+$ in the EBC } \\
\hline \multicolumn{6}{|c|}{ Sex } \\
\hline $\mathrm{F}$ & 38 & । & 39 & $>0.05$ & $4.1(0.5-183.9)$ \\
\hline M & 92 & 10 & 102 & & \\
\hline Total & 130 & 11 & $|4|$ & & \\
\hline \multicolumn{6}{|c|}{ Smokers/ex-smokers ${ }^{\mathrm{a}}$} \\
\hline $\mathrm{N}$ & 34 & 6 & 40 & 0.05 & $0.3(0.07-1.25)$ \\
\hline Y & 96 & 5 & 101 & & \\
\hline Total & 130 & 11 & $|4|$ & & \\
\hline
\end{tabular}

Abbreviations: $\mathrm{Cl}=$ confidence interval; $\mathrm{EBC}=$ exhaled breath condensate; $\mathrm{F}=$ female; $\mathrm{HPV}=$ human papilloma virus; $\mathrm{M}=$ male; $\mathrm{N}=$ no; $\mathrm{OR}=$ odds ratio;

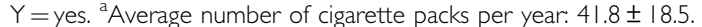

viruses, we were able to detect HPV in the EBC of NSCLC patients that were also found to be HPV positive in paired bronchial brushing and lung tissue (Vogelberg et al, 2003; St George et al, 2010). For the first time the demonstration of the presence of the HPV positivity in the EBC, paired bronchial brushing and lung tissue led us to suppose that the EBC contains identical information on airway colonisation as previously demonstrated for somatic DNA alterations specific to lung cancer (Carpagnano et al, 2008). Our supposition is further supported by the 
Table 4 (a) Exact logistic regression analysis between NSCLCs/controls (dependent variable) and sex, smoking habits and HPV+ in the brushing and lung tissue (independent variables), (b) logistic regression analysis between NSCLCs/controls (dependent variable) and sex, smoking habits and $\mathrm{HPV}+$ in the EBC (independent variables)

\begin{tabular}{|c|c|c|c|}
\hline & OR & $P$ & $95 \% \mathrm{Cl}$ \\
\hline \multicolumn{4}{|l|}{ (a) } \\
\hline $\operatorname{Sex}(M)$ & 1.9 & 0.182 & $0.74-5.01$ \\
\hline Smokers/ex-smokers ${ }^{\mathrm{a}}$ & 6.89 & 0.0001 & $2.3-25.25$ \\
\hline $\mathrm{HPV}+$ in the brushing and lung tissue & 42.8 & $<0.0001$ & From 6 to $+\infty$ \\
\hline \multicolumn{4}{|l|}{ (b) } \\
\hline Sex (M) & 1.8 & 0.197 & $0.7-4.5$ \\
\hline Smokers/ex-smokers ${ }^{\mathrm{a}}$ & 5.8 & 0.0002 & $2.1-19.2$ \\
\hline $\mathrm{HPV}+$ in the EBC & 30.7 & 0.0001 & From 4.3 to $+\infty$ \\
\hline
\end{tabular}

Abbreviations: $\mathrm{Cl}=$ confidence interval; $\mathrm{EBC}=$ exhaled breath condensate; $\mathrm{HPV}=$ human papilloma virus; $\mathrm{M}=$ male; $\mathrm{NSCLC}=$ non-small cell lung cancer; $\mathrm{OR}=$ odds ratio. ${ }^{\mathrm{a}}$ Average number of cigarette packs per year: $41.8 \pm 18.5$.

Table 5 NSCLCs by histotype and HPV+ in the brushing and lung tissue or $\mathrm{HPV}+$ in the EBC

\begin{tabular}{|c|c|c|c|c|c|c|c|}
\hline & \multicolumn{4}{|c|}{ NSCLCs } & \multirow[b]{3}{*}{$\mathbf{N}$} & \multirow[b]{3}{*}{$P$ (Fisher) } & \multirow[b]{3}{*}{ OR $(95 \% \mathrm{Cl})$} \\
\hline & \multicolumn{2}{|c|}{ Squamous } & \multicolumn{2}{|c|}{ Adenocarcinoma } & & & \\
\hline & $N$ & $\%$ & $\mathbf{N}$ & $\%$ & & & \\
\hline \multicolumn{8}{|c|}{ HPV+ in the brushing and lung tissue } \\
\hline No & 33 & $89.2 \%$ & 28 & $77.8 \%$ & 61 & $>0.05$ & $0.4(0.08-1.8)$ \\
\hline Yes & 4 & $10.8 \%$ & 8 & $22.2 \%$ & 12 & & \\
\hline Total & 37 & & 36 & & 73 & & \\
\hline \multicolumn{8}{|c|}{$H P V+$ in the EBC } \\
\hline No & 33 & $89.2 \%$ & 29 & $80.6 \%$ & 62 & $>0.05$ & $0.5(0.1-2.2)$ \\
\hline Yes & 4 & $10.8 \%$ & 7 & $19.4 \%$ & 11 & & \\
\hline Total & 37 & & 36 & & 73 & & \\
\hline
\end{tabular}

Abbreviations: $\mathrm{Cl}=$ confidence interval; $\mathrm{EBC}=$ exhaled breath condensate; $\mathrm{HPV}=$ human papilloma virus; $\mathrm{M}=$ male; $\mathrm{NSCLC}=$ non-small cell lung cancer; $\mathrm{OR}=$ odds ratio

Table 6 Sensitivity and specificity of tests

\begin{tabular}{lc}
\hline & Sensitivity (95\% Cl), \% \\
\hline Cytology $^{\mathrm{a}+}$ & $66(55-77)$ \\
Cytology $^{\mathrm{a}}+$ and HPV+ in the brushing & $73(62-83)$ \\
Cytology $^{\mathrm{a}}+$ and HPV+ in the lung tissue & $73(62-83)$ \\
Cytology + and HPV+ in the EBC & $73(62-83)$ \\
\hline
\end{tabular}

${ }^{\mathrm{a} B r u s h i n g ~ c y t o l o g y .}$

confirmation of our results, which were obtained using the INFINITI HPV-QUAD assay, which allows us to exclude possible false positives due to the high sensitivity of PCR.

Differences with other studies on respiratory viruses and bacteria investigation in the EBC with molecular methods could simply be due to the different pathogens that we investigated as well as differences in the nucleic acid-based techniques used (Vogelberg et al, 2003; St George et al, 2010).

The findings of the involvement of HPV infection in lung cancer are often controversial. Several authors reported that HPV has no role to play in lung cancerogenesis (Shamanin et al, 1994; Gorgoulis et al, 1999; Matakidou et al, 2003), whereas others observed from a low (Béjui-Thivolet et al, 1990; Bohlmeyer et al, 1998; Clavel et al, 2000; Kaya et al, 2001; Syrjänen, 2002) to moderate or to a very high frequency (Yousem et al, 1992; Li et al, 1995; Hirayasu et al, 1996; Tsuhako et al, 1998; Miyagi et al, 2001; Papadakis et al, 2002). We reported a positivity of HPV in $16 \%$ of bronchial brushing cases, paired lung tissue and the EBC of lung cancer patients, which is not only in line with previous data but supports the hypothesis of a causative link between HPV and lung cancer. Differences in HPV percentages are coherent with differences in studies regarding cancer types (NSCLC, SCLC), material (frozen or fresh lung biopsy, paraffin-embedded tissue, BAL etc), methodology (PCR, southern blot technique, in-situ hybridisation), inadequate choice of primers and geographic area analysed. The complete negativity reported in controls is the proof of the specificity of HPV analysis in the bronchial brushing, lung tissue and the EBC of neoplastic patients.

In consideration of the fact that HPV is the second most important cause of lung cancer after cigarette smoke, in order to better understand the co-responsibility of both of these aetiological factors we analysed the HPV infection in relation to the smoking habit and did not report any correlation. Further confirmation of our suggestion is supplied by the result of the logistic regression model applied to variables substantiating that the HPV infection is an independent factor in causing lung cancer.

We reported higher percentages of HPV positivity in lung cancer smokers than in ex smokers or non-smokers. These data found a rationale in the fact that the respiratory epithelium of smokers shows micro-abrasions with squamo-columnar junctions that are considered to be the prerequisite for the spread of HPV (Kashima et al, 1993).

Similar percentages of HPV positivity were reported in both females and males. The sex of patients was not found to influence HPV positivity. These findings are in contrast with those of Cheng et al (2004), who previously described a prevalence of HPV6 in the lung tumours of male patients, indicating that there could be HPV routes for different genders. Differences in number population and in ethnicity could explain differences between our studies, which nevertheless merit to be better investigated in a larger population.

In accordance with previous studies we reported HPV positivity both in adenocarcinoma (An et al, 2005) and in squamous cell carcinoma (Klein et al, 2009). However, despite the higher percentages of HPV positivity in brushing and EBC observed in adenocarcinoma with respect to those in squamous cell carcinoma, they did not reach statistical significance.

According to previous studies (Béjui-Thivolet et al, 1990; Chen et al, 2004; Zafer et al, 2004; Ciotti et al, 2006; Klein et al, 2009; Rezazadeh et al, 2009) we found that the genotypes most prevalent in our population were numbers 16 and 31 , which are also the most oncogenic. However, we also reported one case of HPV 30 and one of HPV 39.

A further finding of this study was the higher percentage of HPV positivity in patients with a more advanced stage of lung cancer. Previously Weichert et al (2009) had described a high presence of HPV in patients with advanced cancer and supposed that this virus could suggest a metastatic disease, which would seem to support the notion that HPV typing, a method routinely used in cervical biopsies for some years now, could be a useful diagnostic tool for discriminating primary from metastatic carcinoma of the lung (Weichert et al, 2009).

The major diffusion of HPV in advanced lung cancer is conceivable as the lung cancer cells (originally HPV negative) are more prone to integrate HPV into the tumour genome than normal cells (Klein et al, 2009).

HPV is generally transmitted via direct mucosa contact (Stanley et al, 2007). In the lung it is not possible and there might be transmission via the air stream, carrying infected cell complexes or particles to the periphery of the lung. Chiou et al (2003) reported 
the detection of HPV 16/18 DNA in the blood, opening our insight into some transmission routes of HPV that are potentially distinct from direct mucosa contact. However, although all the women in our study investigated for eventual HPV positivity to the PAP test resulted negative, a limitation of this study was not exploring the HPV in the blood, which would have permitted us to discuss the hypothesis of systemic transmission. A further limitation of this study was not testing the HPV in partners to exclude the other largely recognised rue of transmission, that is, the sexual one (Chen et al, 2004; Georgieva et al, 2009).

Finally, we observed that associating the HPV test in the EBC, brushing or lung tissue slightly increases the sensibility of the cytology. This finding justifies us in encouraging the undertaking of further studies on this field, as they could offer new, more sensitive screening instruments for lung cancer, a disease still characterised by poor results in terms of early diagnosis.

In conclusion, we can be said to have demonstrated that HPV infection is detectable in the EBC of lung cancer patients and that

\section{REFERENCES}

Aguayo F, Castillo A, Koriyama C, Higashi M, Itoh T, Capetillo M, Shuyama K, Corvalan A, Eizuru Y, Akiba S (2007) Human papillomavirus-16 is integrated in lung carcinomas: a study in Chile. $\mathrm{Br} J$ Cancer 9(1): $85-91$

An HJ, Kim KR, Kim IS, Kim DW, Park MH, Park IA, Suh KS, Seo EJ, Sung SH, Sohn JH, Yoon HK, Chang ED, Cho HI, Han JY, Hong SR, Ahn GH (2005) Prevalence of human papillomavirus DNA in various histological subtypes of cervical adenocarcinoma: a population-based study. Mod Patho 18(4): $528-534$

Béjui-Thivolet F, Liagre N, Chignol MC, Chardonnet Y, Patricot LM (1990) Detection of human papillomavirus DNA in squamous bronchial metaplasia and squamous cell carcinomas of the lung by in situ hybridization using biotinylated probes in paraffin-embedded specimens. Hum Pathol 21(1): 111-116

Bohlmeyer T, Le TN, Shroyer AL, Markham N, Shroyer KR (1998) Detection of human papillomavirus in squamous cell carcinomas of the lung by polymerase chain reaction. Am J Respir Cell Mol Biol 18(2): $265-269$

Branica BV, Smojver-Jezek S, Juros Z, Grgi S, Srpak N, reciæ D, oviæ S (2010) Detection of human papillomaviruses type 16, 18 and 33 in bronchial aspirates of lung carcinoma patients by polymerase chain reaction: a study of 84 cases in Croatia. Coll Antropol 34(1): 159-162

Brouchet L, Valmary S, Dahan M, Didier A, Galateau-Salle F, Brousset P, Degano B (2005) Detection of oncogenic virus genomes and gene products in lung carcinoma. Br J Cancer 92(4): $743-746$

Carpagnano GE, Foschino-Barbaro MP, Spanevello A, Resta O, Carpagnano F, Mulé G, Pinto R, Tommasi S, Paradiso A (2008) 3p microsatellite signature in exhaled breath condensate and tumor tissue of patients with lung cancer. Am J Respir Crit Care Med 177(3): 337-341

Castillo A, Aguayo F, Koriyama C, Shuyama K, Akiba S, Herrera-Goepfert R, Carrascal E, Klinge G, Sánchez J, Eizuru Y (2006) Human papilloma virus in lung carcinomas among three Latin American countries. Oncol Rep 15(4): $883-888$

Chen YC, Chen JH, Richard K, Chen PY, Christiani DC (2004) Lung adenocarcinoma and human papilloma virus infection. Cancer 101(6): $1428-1436$

Cheng YW, Chiou HL, Chen JT, Chou MC, Lin TS, Lai WW, Chen CY, Tsai YY, Lee H (2004) Gender difference in human papillomarvirus infection for non-small cell lung cancer in Taiwan. Lung Cancer 46(2): 165-170

Chiou HL, Wu MF, Liaw YC, Cheng YW, Wong RH, Chen CY, Lee H (2003) The presence of human papillomavirus type 16/18 DNA in blood circulation may act as a risk marker of lung cancer in Taiwan. Cancer 97(6): $1558-1563$

Ciotti M, Giuliani L, Ambrogi V, Ronci C, Benedetto A, Mineo TC, Syrjänen K, Favalli C (2006) Detection and expression of human papillomavirus oncogenes in non-small cell lung cancer. Oncol Rep 16(1): 183-189

Clavel CE, Nawrocki B, Bosseaux B, Poitevin G, Putaud IC, Mangeonjean CC, Monteau M, Birembaut PL (2000) Detection of human papillomavirus DNA in bronchopulmonary carcinomas by hybrid capture II: a study of 185 tumors. Cancer 88(6): $1347-1352$ the EBC could be considered a suitable tool for studying the viral colonisation of airways. The EBC and paired bronchial brushing and lung tissue showed an overlap of the HPV-positivity spectrum that was found to be independent from cigarette smoking in increasing the individual's susceptibility to develop lung cancer. Although it could be useful to confirm our results on a larger population, we retain them very interesting in prospective of what they could represent in terms of the early screening of lung cancer patients and possible program of cancer prevention, such as those already commonly used for cervical cancer.

In consideration of the importance of characterising the role of HPV in lung cancer, we are planning to analyse the HPV physical status (episomal/integrated) in the EBC, bronchial brushing and lung tissue of NSCLC patients in a future study.

\section{Conflict of interest}

The authors declare no conflict of interest.
Coissard CJ, Besson G, Polette MC, Monteau M, Birembaut PL, Clavel CE (2005) Prevalence of human papillomaviruses in lung carcinomas: a study of 218 cases. Mod Pathol 18(12): $1606-1609$

Cubie A (2003) When is an STD not an STD? HPV and cervical cancer. Microbiol Today 30: 58-60

De Villiers EM, Fauquet C, Broker TR, Bernard HU, zur Hausen H (2004) Classification of papillomaviruses. Virology 324(1): 17-27. Review

Erali M, Pattison DC, Wittwer CT, Petti CA (2009) Human papillomavirus genotyping using an automated film-based chip array. J Mol Diagn 11(5): 439-445

Fei Y, Yang J, Hsieh WC, Wu JY, Wu TC, Goan YG, Lee H, Cheng YW (2006) Different human papillomavirus 16/18 infection in Chinese nonsmall cell lung cancer patients living in Wuhan, China. Jpn J Clin Oncol 36(5): $274-279$

Georgieva S, Iordanov V, Sergieva S (2009) Nature of cervical cancer and other HPV - associated cancers. J BUON 14(3): 391-398. Review

Gorgoulis VG, Zacharatos P, Kotsinas A, Kyroudi A, Rassidakis AN, Ikonomopoulos JA, Barbatis C, Herrington CS, Kittas C (1999) Human papilloma virus (HPV) is possibly involved in laryngeal but not in lung carcinogenesis. Hum Pathol 30(3): 274-283

Hirayasu T, Iwamasa T, Kamada Y, Koyanagi Y, Usuda H, Genka K (1996) Human papillomavirus DNA in squamous cell carcinoma of the lung. J Clin Pathol 49(10): 810-817

Kashima H, Mounts P, Leventhal B, Hruban RH (1993) Sites of predilection in recurrent respiratory papillomatosis. Ann Otol Rhinol Laryngol 102 (8 Pt 1): $580-583$

Kaya H, ilodlu E, Inanli S, ciodlu G, Bozkurt SU, Tutkun A, Küllü S (2001) Prevalence of human papillomavirus (HPV) DNA in larynx and lung carcinomas. Pathologica 93(5): $531-534$

Kessis TD, Slebos RJ, Nelson WG, Kastan MB, Plunkett BS, Han SM, Lorincz AT, Hedrick L, Cho KR (1993) Human papillomavirus 16 E6 expression disrupts the p53-mediated cellular response to DNA damage. Proc Natl Acad Sci USA 90(9): 3988-3992

Klein F, Amin Kotb WF, Petersen I (2009) Incidence of human papilloma virus in lung cancer. Lung Cancer 65(1): 13-18

Li Q, Hu K, Pan X, Cao Z, Yang J, Hu S (1995) Detection of human papillomavirus types 16,18 DNA related sequences in bronchogenic carcinoma by polymerase chain reaction. Chin Med J 108(8): 610-614

Matakidou A, Eisen T, Houlston RS (2003) TP53 polymorphisms and lung cancer risk: a systematic review and meta-analysis. Mutagenesis 18(4): $377-385$

Menon MM, Simha MR, Doctor VM (1995) Detection of human papilloma virus (HPV) types in precancerous and cancerous lesions of cervix in Indian women: a preliminary report. Indian J Cancer 32(4): 154-159

Miyagi J, Kinjo T, Tsuhako K, Higa M, Iwamasa T, Kamada Y, Hirayasu T (2001) Extremely high Langerhans cell infiltration contributes to the favourable prognosis of HPV-infected squamous cell carcinoma and adenocarcinoma of the lung. Histopathology 38(4): 355-367

Nadji SA, Mokhtari-Azad T, Mahmoodi M, Yahyapour Y, Naghshvar F, Torabizadeh J, Ziaee AA, Nategh R (2007) Relationship between lung 
cancer and human papilloma virus in north of Iran, Mazandaran province. Cancer Lett 248(1): $41-46$

Papadakis ED, Soulitzis N, Spandidos DA (2002) Association of p53 codon 72 polymorphism with advanced lung cancer: the Arg allele is preferentially retained in tumours arising in Arg/Pro germline heterozygotes. Br J Cancer 87(9): 1013-1018

Papadopoulou K, Labropoulou V, Davaris P, Mavromara P, Tsimara-Papastamatiou H (1998) Detection of human papillomaviruses in squamous cell carcinomas of the lung. Virchows Arch 433(1): 49-54

Rezazadeh A, Laber DA, Ghim SJ, Jenson AB, Kloecker G (2009) The role of human papilloma virus in lung cancer: a review of the evidence. Am J Med Sci 338(1): 64-67

Shamanin V, Delius H, de Villiers EM (1994) Development of a broad spectrum PCR assay for papillomaviruses and its application in screening lung cancer biopsies. J Gen Virol 75(Pt 5): 1149-1156

Srinivasan M, Taioli E, Ragin CC (2009) Human papilloma virus type 16 and 18 in primary lung cancers-a meta-analysis. Carcinogenesis 30(10): $1722-1728$

St George K, Fuschino ME, Mokhiber K, Triner W, Spivack SD (2010) Exhaled breath condensate appears to be an unsuitable specimen type for the detection of influenza viruses with nucleic acid-based methods. J Virol Methods 163(1): 144-146

Stanley MA, Pett MR, Coleman N (2007) HPV: from infection to cancer. Biochem Soc Trans 35(Pt 6): 1456-1460. Review

Syrjänen KJ (1979) Condylomatous changes in neoplastic bronchial epithelium. Report of a case. Respiration 38(5): 299-304

Syrjänen KJ (2002) HPV infections and lung cancer. J Clin Pathol 55(12): 885 - 891. Review

Szabó I, Sepp R, Nakamoto K, Maeda M, Sakamoto H, Uda H (1994) Human papillomavirus not found in squamous and large cell lung carcinomas by polymerase chain reaction. Cancer 73(11): 2740-2744
Tsuhako K, Nakazato I, Hirayasu T, Sunakawa H, Iwamasa T (1998) Human papillomavirus DNA in adenosquamous carcinoma of the lung. J Clin Pathol 51(10): $741-749$

Vogelberg C, Hirsch T, Rösen-Wolff A, Kerkmann ML, Leupold W (2003) Pseudomonas aeruginosa and Burkholderia cepacia cannot be detected by PCR in the breath condensate of patients with cystic fibrosis. Pediatr Pulmonol 36(4): $348-352$

Wang Y, Wang A, Jiang R, Pan H, Huang B, Lu Y, Wu C (2008) Human papillomavirus type 16 and 18 infection is associated with lung cancer patients from the central part of China. Oncol Rep 20(2): 333-339

Weichert W, Schewe C, Denkert C, Morawietz L, Dietel M, Petersen I (2009) Molecular HPV typing as a diagnostic tool to discriminate primary from metastatic squamous cell carcinoma of the lung. Am J Surg Pathol 33(4): $513-520$

Werness BA, Levine AJ, Howley PM (1990) Association of human papilloma virus types 16 and 18 E6 proteins with p53. Science 248(4951): $76-79$

Yousem SA, Ohori NP, Sonmez-Alpan E (1992) Occurrence of human papillomavirus DNA in primary lung neoplasms. Cancer 69(3): 693-697

Zafer E, Ergun MA, Alver G, Sahin FI, Yavuzer S, Ekmekci A (2004) Detection and typing of human papillomavirus in non-small cell lung cancer. Respiration 71(1): $88-90$

Zur Hausen H (2001) Cervical carcinoma and human papillomavirus: on the road to preventing a major human cancer. J Natl Cancer Inst 93(4): $252-253$

Zur Hausen H (2002) Papillomaviruses and cancer: from basic studies to clinical application. Nat Rev Cancer 2(5): $342-350$. Review

Zur Hausen J, Meinhof W, Scheiber W, Bornkamm GW (1974) Attempts to detect virus-specific DNA in human tumors. I. Nucleic acid hybridizations with complementary RNA of human wart virus. Int J Cancer 13(5): $657-664$

This work is published under the standard license to publish agreement. After 12 months the work will become freely available and the license terms will switch to a Creative Commons Attribution-NonCommercial-Share Alike 3.0 Unported License. 